\title{
A CIDADE, O VERDADEIRO E O FALSO EM PARMÊNIDES
}

\author{
Giovanni Casertano ${ }^{1}$ \\ casertan@unina.it
}

a Antonio Capizzi in memoriam

RESUMO Parte da historiografia filosófica da segunda metade do século XIX se empenha em renovar a imagem de Parmênides de Eléia fixada pela tradição - filósofo do imobilismo, isolado, estranho e venerável - recuperando as relações estreitas que ele mantinha com as exigências da cultura de sua época. O propósito deste artigo é reconduzir Parmênides ao seu tempo, apontando o pensamento vivo de um homem que foi não apenas filósofo, mas também cientista e político de grande relevo.

Palavras-chave Parmênides de Eléia; História da Filosofia Antiga; Filosofia Pré-Socrática.

ABSTRACT Part of the late 19th century philosophical historiography attempts to renew the image of Parmenides of Elea, consolidated by tradition as an isolated, strange and venerable philosopher of immobilism, recovering the intimate relations he had with the cultural demands of his time. The purpose of this article is to reconnect Parmenides with his time by presenting

1 Professor de História da Filosofia Antiga, na Università degli Studi di Napoli "Federico II", Nápoles, Itália. Artigo traduzido por Karina L. Fabrini (karinafabrini@ oi.com.br) e Miriam C. D. Peixoto (miriam71@terra. com.br), recebido em setembro e aprovado em outubro de 2007.

KRITERION, Belo Horizonte, nº 116, Dez/2007, p. 307-327. 
the lively thought of a man who was not only a philosopher but also a scientist and a politician of great relevance.

Keywords Parmenides of Elea; History of Ancient Philosophy; PreSocratic Philosophy.

Sobre os grandes filósofos existem, com freqüência, lendas que são transmitidas através dos séculos; não somente as lendas que acompanham a sua vida e seus episódios, mas também as que fixam as coordenadas do seu pensamento e da sua reflexão teórica. Assim aconteceu também com Parmênides, do qual foi bem depressa construída uma imagem que imobilizou sua doutrina em caracteres bem precisos, "falsificando-a" de maneira mais ou menos arbitrária. E isso acontece desde o início, se é verdade - mas não há razão para duvidar - que seu grande aluno Zenão teve que defender a doutrina do mestre dos numerosos opositores que a criticavam e deformavam. ${ }^{2}$ Parmênides aparece, pois, bem depressa como um filósofo "isolado", fora do contexto cultural no qual atuava, ao qual suas teses pareciam estranhas e inusitadas. Para Platão, que já o considerava um "antigo", cuja palavra era difícil de ser compreendida plenamente porque parecia que falava como "acima das nossas cabeças", ele era um "pai venerando e terrível", ${ }^{3}$ mas um pai incômodo, com o qual era difícil acertar as contas, que talvez fosse necessário matar, ${ }^{5}$ mas somente para fazê-lo renascer, e, portanto, salvá-lo. Depois de Platão, Aristóteles fixou as características da sua doutrina na imagem do stasiotes, do imobilizador da realidade, ${ }^{6}$ e com estas características a imagem de Parmênides viajou da Antigüidade até nós.

Mas quais são essas características? Uma filosofia que nega a multiplicidade dos fenômenos para sustentar a unicidade e a imobilidade de uma realidade sempre imutável e estática; que considera também a realidade fenomênica como uma simples aparência privada de qualquer valor gnosiológico e ontológico; que sustenta a existência somente do "ser", um ser entre outras

4 Plat. Theaet. 183e. Sócrates acrescenta que, mesmo the parecendo Parmênides homem de uma "profundidade nobre sob todos os aspectos", temia não conseguir compreender as suas palavras e ainda mais qual fosse o seu pensamento (184a).

5 Plat. Soph. 241d.

6 Plat. Theaet. 181a; Aristot. p.f. fr. 9 Ross. 
coisas dificilmente compreensível e interpretado desde a Antigüidade das maneiras as mais diversas, como uma entidade ontologicamente separada e abstrata, quase divina, ou como expressão de uma simples forma verbal; que estabelece uma fratura insanável entre verdade e opinião e, logo, entre razão e sensibilidade, instaurando também uma nítida dicotomia de valores entre um plano e o outro; uma filosofia, por isso que está na origem, ao mesmo tempo, do racionalismo, do antiempirismo, da anticientificidade, do pensamento metafísico e, logo, da "metafísica ocidental", e assim por diante. É verdade que, especialmente na historiografia filosófica da segunda metade do século XIX, existiram muitos trabalhos de estudiosos que se empenharam em redimensionar esta imagem e em remeter o pensamento de Parmênides às mais concretas exigências culturais da sua época e do seu ambiente, mostrando o estreito liame que a elas unia o filósofo de Eléia. Pessoalmente, creio que esta seja a linha historiográfica a ser perseguida, e que no seu interior muito haja ainda para esclarecer e interpretar. Porque este tipo de investigação não somente "historiciza" melhor o seu pensamento, enraizando-o em um mundo concreto de debates, de polêmicas, de tomadas de posição sobre problemas gnosiológicos, mas também de epistemologia, de astronomia, de física, de biologia, de embriologia, de política; mas, principalmente, porque desse modo se faz sobressair melhor a sua originalidade e a sua força especulativa. $\mathrm{O}$ fato de que sua originalidade e sua força foram certamente grandes impressionou não somente um Platão e um Aristóteles, mas também um Hegel e um Einstein.

A partir deste trabalho de "desestratificação" e de redimensionamento das doutrinas parmenídicas, o poema do Eleata, nos cerca de 160 versos que nos foram conservados dele, ganhou nova luz e, ainda que alguns detalhes possam parecer fugidios e desbotados, o esboço geral da obra nos é bastante claro. Há uma introdução, elevada e inspirada, um prólogo no estilo da tradição épica, que narra uma experiência intelectual extraordinária, a "revelação" de uma deusa. Mas uma revelação que não tem nada de místico ou de "mistérico" e que não é nada mais do que o delineamento de um ambicioso programa de pesquisa que possa conduzir a conhecer todas as coisas, em todos os sentidos, em todos os campos do saber humano. Há, em seguida, uma aguda discussão sobre a "via" que conduz a esse saber, isto é, uma discussão sobre o método com o qual se pode construir esse saber e que distingue nitidamente o homem que sabe dos homens que nada sabem, que têm peitos e mentes indecisos, que se deixam arrastar, surdos e cegos, pelos tortuosos caminhos da vida, que não sabem julgar. Há, depois, a grandiosa intuição da relação que une e distingue a experiência de todos os dias, o mundo polimorfo das coisas que acontecem e sobre as quais não há certeza e o mundo abstrato e formalizado da verdade 
científica, aquele mundo da verdade sem contradições: o coração da verdade bem redonda que somente a poucos é dado alcançar. Há, enfim, o cenário grandioso e solene no qual se movem os astros e a terra, as estrelas e os homens, com seus desejos e suas paixões, suas aspirações e seus pensamentos, seus corpos e suas mentes. O todo mesurado pela inflexível lei de uma Necessidade racional e eterna, que sustenta no interior dos seus potentes liames toda a identidade e todas as diferenças das coisas que nascem, que são e deixam de ser.

Reconduzir Parmênides ao seu tempo, portanto, "historicizar" Parmênides não significa fazer uma obra de "restauração" em um pensamento já sepulto e que não tem mais nada a nos dizer, mas colher, tanto quanto possível, o pensamento vivo, concreto, de um homem que não foi somente um filósofo, mas também um cientista e um político de grande relevância; definitivamente, quando essa "historicização" de grandes figuras não é feita por pura erudição, ela significa que se pode experimentar hoje o interesse que ainda tem para nós um pensamento, uma intuição, uma doutrina. Tentarei aqui esboçar em linhas gerais essa obra de redimensionamento da figura de Parmênides a partir de um tríplice ponto de vista, filosófico, científico e político.

1. Se a grande filosofia grega leva os nomes de Platão e de Aristóteles e o seu drama se desenrola em Atenas, centro do mundo grego, existiram também pólos não menos grandiosos, a Leste e a Oeste daquele centro, sem os quais aquela luz não teria sido acesa. No Oriente houve o pensamento científico dos milesianos, mas também a inquietante e ambígua palavra de Heráclito. No Ocidente apareceram dois poemas que lançaram as bases e delinearam os contornos daquelas que foram, a partir de então, a filosofia, a filosofia da natureza e a metodologia científica: em Eléia, o livro de Parmênides; mais ao Sul, na Sicília meridional, um pouco mais tarde, o livro daquele extraordinário filósofo, cientista, visionário e poeta, que vivia na dourada cidade de Akragas. Entre o Oriente e o Ocidente se moviam os Pitagóricos: Parmênides teve um contato particularmente íntimo com as doutrinas pitagóricas, que foram transmitidas do extremo oriente do mundo grego, no fim do século VI, à Grécia ocidental; nelas ele foi iniciado, provavelmente, pelo seu mestre Amínias, um pitagórico pobre, mas nobre e probo e em honra do qual ele, riquíssimo, construiu um santuário. ${ }^{7}$ Tal como os Pitagóricos, também Parmênides individualizou dois princípios contrários (tanantia), ${ }^{8}$ "fogo" e "noite", dos quais "tudo é pleno... uma vez que cada coisa resulta do conjunto 
dos dois". ${ }^{9}$ Mas Parmênides não foi um simples repetidor de doutrinas pitagóricas, antes as criticou especialmente e fortemente em um ponto capital. Como fica explicitamente claro pelas teses polêmicas do seu grande aluno Zenão, mas também tal como já resulta de seus versos, Parmênides pensou o cosmo segundo o paradigma da continuidade: à descontinuidade de uma realidade composta e estruturada por números-unidades, sustentada pelas antigas doutrinas pitagóricas, ele contrapõe uma concepção do cosmo que tem as características do oulomelés do hen e do synechés, ${ }^{10}$ isto é, da compacidade, da unidade e da continuidade. A importância dessa polêmica, que nasce na Grécia de 2500 anos atrás, a polêmica acerca do continuum-discretum que opunha na Antigüidade Parmênides aos Pitagóricos, torna-se evidente se pensarmos no fato de que, ainda hoje, as discussões entre os que sustentam teorias ondulatórias e os que sustentam teorias corpusculares não parecem ter encontrado um acordo definitivo; basta mencionar os grandes nomes de Planck, de De Broglie, de Einstein, de Heisenberg ou de Schrödinger.

A figura de Parmênides torna-se, assim, perfeitamente inserida em um vivo debate científico sobre um problema determinado, bem distante, porém, daquela imagem do filósofo empenhado em dissertações abstratamente metafísicas e que desprezam a experiência. De resto, que Parmênides se insira plenamente no contexto daquele comportamento científico geral do século $\mathrm{V}$ a.C. no que concerne à especulação sobre o homem, resulta claramente dos testemunhos autorais de Aristóteles e de Teofrasto, além de uma longa série de testemunhos antigos, aos quais se deu pouca importância, justamente porque desde então era "vencedora" uma outra imagem. ${ }^{11}$ No livro IV da Metafísica, num discurso que quer refutar o relativismo gnosiológico de Protágoras, um discurso preocupado em criticar o estreito liame que une phronesis a aisthesis, a inteligência, o pensamento à sensação, Aristóteles, ${ }^{12}$ como defensor de tais doutrinas, cita Parmênides junto com Empédocles, Demócrito e Anaxágoras, e os liga diretamente a Homero, que, em um famoso passo da Ilíada $(23,698)$, havia dito que o herói, delirante pela ferida, "jazia com pensamentos alterados na sua mente". Também Teofrasto, em um discurso centrado na sensação, e preocupado em distinguir aqueles que admitiam que ela ocorre segundo o

9 DK28B 9, 3-4.

10 DK28B 8, 4-6.

11 Cf. Diógenes Laércio (IC 21-23 = DK28A 1), Suda (s.v.), Jâmblico (v. Pith. $166=$ DK28A 4), Eusébio (chron. A) Hieron = DK28A 11), Simplício (de caelo 556, $25=$ DK 28A14), Menandro ([mais exatamente Genethlios] reth. I 2, 2; I 5,2 = DK28 A 20), Hipólito (ólito ref. I 11 = DK 28 A 23), Plutarco (adv. Col. 1114 b).

12 met. 1009 b 1-14. 
princípio do "semelhante com o semelhante" (Parmênides, Empédocles e Platão) daqueles que sustentavam que ela advém segundo o princípio do "contrário" (Anaxágoras e Heráclito), também ele, em substância, testemunha que, para Parmênides, não somente a dianoia é sempre symmetria, mas existe uma identificação direta de aisthanesthai e de phronein, isto é, precisamente de sentir e pensar. ${ }^{13}$

Mas sobre este ponto, felizmente, dispomos dos versos originais de Parmênides, que os mesmos Aristóteles e Teofrasto citam para confirmar as próprias argumentações. Tratam-se dos quatro versos do importantíssimo fragmento 16, que dizem o seguinte:

E, de fato, conforme a relação que em cada um se instaura entre as partes móveis que o constituem, assim nos homens se determina a mente; uma vez que é sempre o mesmo aquilo que nos homens pensa: a natureza das suas partes constituintes, em todos e em cada um. O pensamento é, de fato, o conjunto de todas estas relações.

O fragmento se apresenta, nos quatro versos que nos chegaram, extraordinariamente compacto na sua estrutura lógica e sintática e extremamente claro na sua formulação conceitual. Ao ligar estreitamente o pensamento e o pensado à natureza das partes constituintes do corpo, se é que para cada homem resulta uma unidade incindível de corpo e pensamento, esta é uma prova ulterior da impossibilidade de se separar e contrapor, em Parmênides, racionalidade e sensibilidade. Existe uma estreita relação entre os mélea, as partes constituintes de cada homem, e o seu noos, seu intelecto. O sentido dessa relação é que é sempre a physis meleon, isto é, a configuração particular que assume em cada homem a síntese entre as suas partes constitutivas, que determina o seu pensamento. É sempre ela, de fato, aquilo que pensa, nos homens; e, de fato, o noema exprime, assim, a totalidade do homem (to pleon), sendo a significação mais forte do seu ser no sentido mais pleno.

Mas se Parmênides se encontra na origem da origem da filosofia, ele está, também, na origem do problema da verdade. Também a propósito desse problema gostaria de me deter, em particular, para mostrar como se torna muito mais interessante aproximar-se do texto parmenídico, prescindindo da imagem vulgata de sua filosofia. Como é notório, se quis ver por séculos uma fratura no interior do poema parmenídico, fratura que seria assinalada nos versos 50-51 do fragmento 8: "Com isso interrompo o discurso certo e o pensamento / em torno da verdade; doravante aprende as opiniões dos 
homens". Sobre essa base se construiu uma improvável dicotomia entre as duas partes do poema, a primeira dedicada à "verdade", a segunda às "opiniões". Na primeira, Parmênides exporia as linhas de uma filosofia "verdadeira" do ser (o que quer que deva significar esse ser); na segunda, as linhas de um enganoso quadro das opiniões dos homens e, portanto, toda uma cosmologia e uma antropologia, em suma, uma filosofia da natureza fundamentalmente "falsa". Desse modo, de maneira muito simplista, se resolvia o problema da verdade em Parmênides: verdadeiro é o ser, e, portanto, o discurso sobre o ser; falsas são as opiniões, e, portanto, todo discurso sobre as opiniões. Mas a historiografia filosófica mais atenta desmantelou desde então esse quadro, não somente "costurando" as duas partes do poema parmenídico e conferindo, portanto, densidade e dignidade filosófica também ao discurso sobre as opiniões, mas, ainda, aprofundando os estreitos laços teóricos que existem entre as duas partes. Nesse quadro não somente de revalorização da doxa parmenídica, mas também de reconsideração do sentido da unicidade do seu pensamento, me movi, também eu, com um volume escrito aproximadamente há 30 anos. ${ }^{14}$ Aquilo que, ao contrário, gostaria de tentar aqui é uma análise do sentido e das condições da verdade em Parmênides, para mostrar como a sua posição não é de fato monolítica, mas contém no seu interior brechas teóricas que, tendo sido sabiamente utilizadas pelos sofistas, em particular por Protágoras e por Górgias, Platão, em seguida, tentará recompor em um contexto difícil de fidelidade e, ao mesmo tempo, de superação da perspectiva do Eleata.

Com efeito, a verdade é um problema também para Parmênides. Problema porque, mesmo sendo bastante claras as coordenadas teóricas nas quais se situa a sua perspectiva, não é fácil esclarecer seu significado e suas implicações. O fragmento 3 (“de fato é a mesma coisa pensar e ser"), lido fora de todo horizonte neoplatônico ou idealista, no qual nos foi transmitido a partir de Plotino, nos fala somente de uma coincidência, de uma identidade ou de uma não-cindibilidade. Mas enquanto o "pensar" é de fácil entendimento, mais difícil se torna entender o campo semântico do einai, do "ser". Como se pode notar, ao indicar o objeto da sua pesquisa, Parmênides não usa o termo "ser", mas antes to eon, o ente, "aquilo que é". O problema se complica porque, ao lado de "aquilo que é" aparece também um to me eon, um nãoente, "aquilo que não é", e dele se diz explicitamente que não é cognoscível, nem exprimível (B 2.7-8: oute gnoies...oute frasais) não sendo, portanto, 
evidentemente, pensável. Há, pois, uma estreita relação entre a seqüência: ser - pensar - conhecer, e, de modo especular, a outra: não ser - não pensar - não conhecer. As duas seqüências poderiam também verossimilmente se enriquecer, respectivamente, de um "exprimir - dizer" e de um "não exprimir - não dizer", com base, por exemplo, no verso 1 do fragmento 6 , no qual o legein, o dizer, é necessariamente ligado ao noein, ao pensar. ${ }^{15}$

Ora, todos os semata, os "sinais", de B8 dizem respeito "àquilo que é": ingênito, indestrutível, compacto, imutável, e assim por diante, em suma, os "sinais" "daquilo que é" são as modalidades nas quais ele pode ser pensado/ dito. Vejamos. O fragmento 6 e o fragmento 8, 8-9 dizem o seguinte: "é preciso dizer e pensar que aquilo que é existe"; "[aquilo que não é] não é dizível, nem pensável uma vez que não existe". Portanto, o plano semântico "daquilo que é", como delineado no fragmento 8, é o plano da realidade física, existencial, formalizado precisamente na forma lingüística to eon; essa indica o todo, o cosmo das coisas existentes, mas que é visto através de um movimento de abstração do pensamento, na sua unidade que prescinde da multiplicidade dos fenômenos particulares que nele se manifestam. Digamos logo que esta não é uma perspectiva original de Parmênides: desde Tales, se é verdadeira a sua afirmação que diz hena ton kosmon ${ }^{16}$ - mas não há nenhum motivo para duvidar que o seja -, a unidade e a unicidade do cosmo (que não excluem obviamente a multiplicidade dos mundos possíveis que o constituem) são doutrinas dominantes na reflexão grega. É o que testemunha com autoridade Aristóteles, para "todos aqueles que primeiro filosofaram", ${ }^{17}$ acrescentando que nessa perspectiva "nada nasce e nada se destrói”, tal como já havia poetizado Xenófanes naquelas duas afirmações, só aparentemente contraditórias, nas quais, por um lado, se diz que nada nasce, nem se destrói, nem se move, uma vez que o uno-todo é isento de mudança ${ }^{18}$ e, por outro lado, que tudo aquilo que nasce é perecível. ${ }^{19}$

Também para Parmênides o uno-todo é precisamente ingênito, indestrutível, compacto, contínuo, homogêneo (B8), enquanto "as coisas que são", os fenômenos particulares, nascem e terão um fim (B19). Antes e depois de Parmênides, com Anaximandro, Anaxímenes, Melisso, Filolau, Heráclito, Empédocles, Anaxágoras e Demócrito, se disse e se repetirá que o nascimento e a morte são nomes de acontecimentos que se referem a fenômenos particulares

15 B 6,1: chre to legein te noein t’eon émmenai. Sobre esta estreita relação, cf., também, B 8, 8; B 8,17.

16 Aet. II 1, 2 = DK11A 13b.

17 Arist. Met. A 3.983 b 6.

18 Hippol. Ref. I 14, 2 = DK 21 A 33.

19 DL IX 19 = DK21A 1. 
que se desenrolam na realidade, mas não concernem em nada e não podem ser aplicados à realidade entendida como uno-todo. ${ }^{20}$

Os dois aspectos absolutamente novos em Parmênides são, ao contrário, por um lado, a demonstração lógica e formal das duas teses que se desenvolve fundamentalmente nos versos centrais do fragmento 8, e, por outro lado, a clara teorização do método ou da "via de pesquisa" (B2-B7), através da qual se podem alcançar as duas ordens de afirmações. O segundo desses aspectos é precisamente aquele que diz respeito de perto ao problema da verdade. Afirmada a identidade entre pensar e ser, podemos entender essa identidade no sentido de que cada vez que se pensa, se pensa algo que é, isto é, que existe, enquanto não se pode pensar algo que não é, isto é, que não existe. Assim, B 8.34: "e é a mesma coisa o pensar e aquilo que é pensado". ${ }^{21}$ Isso significa não somente que o pensar está inseparavelmente conectado ao pensado, pela evidente razão que não pode ocorrer um pensamento que não seja pensamento de alguma coisa, mas também pela razão mais profunda segundo a qual o pensamento se enraíza no ser, no sentido de que não é concebível um pensamento que não seja da realidade ou - mas dá no mesmo - que há sempre uma realidade que se exprime no pensamento. Assim, de fato, nos versos seguintes: "já que sem aquilo que é, nos limites do qual é expresso, não encontrarás o pensar; nenhuma outra coisa de fato existe ou existirá fora daquilo que é". ${ }^{22} \mathrm{O}$ pensar se enraíza, portanto, no ser, está encadeado aos limites da realidade, para usar a forte expressão do verso $31,{ }^{23}$ e cada vez que se pensa e, portanto, se diz algo pensado, se pensa, e, portanto, se diz uma realidade. De modo especular não existe, nem se pode pensar, e, portanto, não se pode dizer, uma não-realidade, alguma coisa que não é.

Tudo isto é bastante claro. O problema surge quando o ser e o pensar se conjugam precisamente com a "verdade". Pensar e dizer o ser, ou seja, algo real, é evidentemente pensar e dizer a verdade. Todo discurso sobre to eon, sobre a realidade, com todas as suas demonstrações, seus princípios lógicos, a explicação das características e das determinações "daquilo que é", é explicitamente um discurso amphi alethéies que se move no reino e nos confins da verdade. ${ }^{24}$ A verdade, para Parmênides, está estreitamente ligada

20 Anaximandro: DK 12A1; Anaxímenes: DK13A 11; Melisso: DK30A 5, A 10, B 1, B 7-8; Filolau: DK44A 16, B 21; Heráclito: DK22A 6; Empédocles: DK31B 8, B 9; Anaxágoras: DK59B 17; Demócrito: DK68A 37, A 49, A 57-59.

21 Os vv. 34-36 deste fragmento são, como se pode notar, de difícil restituição e interpretação. Para a minha interpretação e para a discussão de outras interpretações, cf. o ensaio citado na nota 13.

22 B 8, 35-37.

23 B 8, 31: peiratos en desmoisin.

24 B 8, 51. 
à persuasão; o caminho da persuasão, de fato, "segue" a verdade: ${ }^{25}$ tudo o que foi dito sobre to eon é, de fato, não somente um discurso verdadeiro, mas também um pistos logos, um discurso digno de fé, logo, crível. ${ }^{26}$ É preciso sublinhar, o que não sempre é feito, essa estreita conexão em Parmênides, como depois em Górgias e, naturalmente, em Platão, entre verdade e persuasão: um discurso verdadeiro é sempre um discurso que convence, que persuade. Esse é, acima de tudo, o discurso sobre to eon, o discurso sobre a realidade entendida como uno, como todo, na determinação lógica e necessária das suas características fundamentais. Mas a verdade do discurso sobre to eon é, ao mesmo tempo, o constituir-se mesmo desse discurso: em outras palavras, o método ou aquilo que Parmênides chama de hodos dizesios, a via de pesquisa. É somente a via de pesquisa que persegue to eon que constitui um caminho (kéleuthos) rumo à verdade, enquanto aquela que pretende falar de to me eon é um atarpòs, uma senda de todo intransitável, porque "aquilo que não é" não se pode nem conhecer nem exprimir. ${ }^{27}$ Como indiquei anteriormente, essa ótica parece monolítica em sua tentativa de estabelecer diferenças, conexões e exclusões nítidas, mas monolítica ela não é, justamente pela introdução do fator "persuasão".

Se o reino da verdade coincide com o reino do ser, isto é, da realidade, o reino do não ser, isto é, do não real, deveria ser aquele da falsidade: portanto, se dizer a verdade significa dizer coisas que são, dizer a falsidade deveria significar dizer coisas que não são. O problema é que essas equações não são nunca afirmadas explicitamente por Parmênides, mesmo se, no que diz respeito à primeira, ela pode ser deduzida bastante legitimamente, como vimos. Aquilo que, ao contrário, é explicitamente negado é precisamente que se possa pensar e dizer aquilo que não é. Os primeiros dois versos de B7, que são justamente aqueles citados por Platão no Sofista, ${ }^{28}$ dizem que "nunca se poderá impor pela força isto, que existem as coisas que não existem. Mas tu afasta o pensamento dessa via de investigação." Já vimos que "aquilo que não é” não pode ser dito nem pensado, a partir do momento que não existe, ${ }^{29} \mathrm{e}$ que algo de impensável e de inexprimível não seja nem mesmo "verdadeiro" é reforçado logo depois, nos versos 17-18 do mesmo B8: uma das vias de investigação é "impensável e inexprimível (não é a verdadeira via, de fato), enquanto a outra existe e é autêntica (etetymon)", sendo que o termo etetymon oferece uma significativa 
remissão, seja ao plano da realidade, seja àquele da verdade. Portanto: se não é possível pensar e dizer aquilo que não é; se só é possível pensar e dizer aquilo que é; e se, cada vez que se pensa e se diz aquilo que é, se pensa e se diz a verdade, a conseqüência do ditado de Parmênides deveria ser precisamente aquela que dela deduzem os sofistas, em particular Protágoras e Górgias, ou seja, que, cada vez que se diz, se diz sempre a verdade, e, portanto, que todos os discursos são verdadeiros. Mas seria mesmo assim?

Com efeito, essa potente perspectiva, que liga a verdade ao ser, proclamando pensável e dizível somente o ser, e que, todavia, estabelece, em termos nossos, uma analogia, ou uma identidade, entre as leis do real e as do pensamento, pressuposto que foi e é fundamental para o desenvolvimento do pensamento científico e filosófico, apresenta no seu interior fissuras perigosas, muito antes que as refinadas análises de um Górgias o mostrassem e o divulgassem. Parmênides, de fato, convida a bem refletir ("faça tesouro do discurso que ouve"), em B2, sobre as "únicas vias de pesquisa pensáveis", ${ }^{30}$ uma das quais ouk esti me einai, ou seja, não pode não existir, e é precisamente o caminho da verdade que não pode não gerar persuasão, enquanto a outra é de todo não transitável. Esta via intransitável é, evidentemente, aquela (ou aquelas) de B6, sobre a qual se movem os homens "de duas cabeças", que afirmam o ser e o não ser, o existir e o não existir como tauton, a mesma coisa. Isso significa que um discurso sobre aquilo que não é, portanto, um discurso não verdadeiro, pode de toda maneira ser feito: em B8, 50, de fato, se põe fim ao discurso certo e ao pensamento em torno da verdade, mas não por isto o discurso cessa: se inicia um outro, que, se não é verdadeiro, não é de maneira alguma menos importante para o vasto programa do saber prenunciado nos últimos versos do fragmento 1: "É necessário que tu aprendas todas as coisas, seja o fundo imutável da verdade sem contradições, seja as experiências dos homens, nas quais não há certeza verdadeira. Mas a todo preço também essas aprenderás, uma vez que as experiências devem ter um valor próprio, para aquele que indaga tudo em todos os sentidos". ${ }^{31}$

O discurso sobre as opiniões, isto é, sobre as experiências dos homens, que certamente não tem o grau de verdade daquele sobre to eon, é parte indispensável da construção do conhecimento humano: é um discurso "não verdadeiro", mas nem por isto é um discurso "falso". Em B2, a via de investigação, se não é uma verdadeira e própria hodòs, é de alguma maneira um atarpòs, um kéleuthos,

30 B $2,2$.

31 B 1, 28-32. Para a justificação dessa tradução e principalmente para a compreensão de doxai como "experiências", veja-se o meu ensaio citado anteriormente, em particular n. 32, p. 56-59 e p. 203-213. 
e mesmo se não é transitável (é antes de tudo intransitável), pode de algum modo ser pensada, a partir do momento que faz parte das únicas vias que podem ser pensadas (noésai). Logo, pode-se pensar e dizer também o falso, como fazem não somente os dikranoi de B6, 5, que é gente que não sabe julgar (akrita phyla) e que mistura nos próprios discursos o ser e o não ser, o existir e o não existir, mas como fazem também aqueles que falam sem método da natureza. Aqueles, de fato, confundindo as vias, atribuem "àquilo que é" os nomes "nascer", "morrer" 32 e "mudar", que rigorosamente não podem ser atribuídos a ele, uma vez que são características não "daquilo que é”, mas das "coisas que são" e, logo, das singularidades múltiplas dos fenômenos. Não apenas isso, mas nessa sua equivocada operação, "crêem serem verdadeiros" aqueles nomes $(B 8,39)$. Portanto, como se vê, também para Parmênides, podese dizer o que não é verdadeiro: e, ainda, pode-se também crer na verdade do não verdadeiro que se diz. Nisso precisamente consiste o erro fundamental dos homens, que constitui um erro fundamentalmente metodológico: eles atribuem as características "daquilo que é" às "coisas que são" e vice-versa; atribuem, portanto, as características da imutabilidade, da homogeneidade, da continuidade e da unidade à multiplicidade dos fenômenos mutantes e passageiros, sendo que elas são próprias apenas da realidade compreendida em sua totalidade; e, inversamente, as características da mudança, da multiplicidade, da descontinuidade, do nascer e perecer são atribuídas "àquilo que é", sendo que elas são próprias apenas das "coisas que são".

É claro que a perspectiva hermenêutica aqui traçada faz parte de uma reconsideração positiva da doxa parmenídica, intimamente entrelaçada com aletheia, num quadro de conhecimento da realidade que seja o mais amplo e o mais compreensível do todo que é possível. Se é somente o discurso sobre to eon que é verdadeiro, porque é um discurso metodológico, matemático e geométrico, o discurso sobre as opiniões, ou sobre as experiências dos homens, mesmo não sendo verdadeiro, não é todavia falso: é verossímil, assim como todo discurso sobre a realidade física, sobre a fenomenalidade, de Parmênides a Platão (lembremos o eikòs do Timeu), a Einstein ("se é certo, não é física").

2. O mundo das doxai humanas sobre o mundo físico ou sobre a natureza constitui, então, o outro grande campo de pesquisa do pensamento parmenídico. Certamente, não é fácil reconstruir as suas doutrinas cosmológicas, físicas, biológicas e antropológicas, mesmo porque do poema parmenídico nos chegou

32 B 8, 39-41: “Com relação a ele [aquilo que é] são dados todos os nomes que os homens estabeleceram acreditando serem verdadeiros, ou seja, nascer e morrer, existir e não existir, mudar de lugar e mudar de resplandecente cor". 
quase por inteiro a primeira parte, aquela que, na historiografia tradicional desde a Antigüidade, era chamada precisamente de "verdadeira", enquanto, da segunda parte, na qual esses problemas eram enfrentados, podemos ler muito pouco. Mas não tão pouco a ponto de não podermos esboçar as linhas de um sistema teoricamente compacto e que se inseria bem nas especulações dos primeiros filósofos-cientistas da Grécia arcaica.

Uma realidade material, na origem, princípio de todas as coisas, incluindo o homem, nos foi atestada claramente por Parmênides por numerosos testemunhos; todos falam de uma realidade dinâmica, em movimento, resultante do dialético encontrar-se de dois "princípios" contrários, dos quais e mediante os quais tem origem aquela variedade de formas e de fenômenos que distinguem o cosmo, como lembrei anteriormente. Uma realidade eterna, ${ }^{33}$ então, e dinâmica: podemos imaginar, com base num testemunho de PseudoPlutarco, um caos primitivo e um movimento em vórtice do qual se origina a matéria, da qual tenham tido origem as várias partes do cosmo. Com efeito, a terra, elemento denso e pesado, vem a encontrar-se no centro e assume, em razão deste movimento, uma forma esférica: "Diz, além disso, [Parmênides] que a terra se formou por precipitação do elemento denso." 34 "Foi ele o primeiro a dizer que a terra é esférica e que ocupa o centro do universo." ${ }^{35}$ Assim, o ar é secreção da terra, o sol e a Via Láctea são exalações do fogo, ${ }^{36}$ o céu é de fogo, ${ }^{37}$ os astros são massas de fogo condensado, ${ }^{38}$ o sol é de fogo e doa a sua luz à lua. ${ }^{39}$ Parmênides foi também um dos primeiros a sustentar que as estrelas Matutina e Vespertina são a mesma. ${ }^{40}$ Parece, enfim, que Parmênides tenha feito primeiramente uma divisão da terra em cinco zonas, determinando nela os lugares habitados abaixo das zonas temperadas. ${ }^{41}$ Notícias, como se vê, mas que demonstram muito mais que um interesse vago de Parmênides pela cosmologia, ou uma sua "concessão" às "opiniões" dos homens, mas antes um corpus de doutrinas organicamente estruturado.

Mas há mais; há um outro testemunho que me parece muito significativo para a perspectiva de um Parmênides estudioso da natureza. A terra teve origem, como todos os astros, a partir de uma matéria primogênita e, ainda,

33 Numerosos os testemunhos sobre a eternidade da realidade: recordemos Arist. Phys. 191a24; metaph, 984a27; de cael. 298b14; Theophr. phys.opin. fr.6; Euseb. p.e. I 8,5.

34 [Plutarch.] strom. 5= DKA22.

35 DL IX 21= DK28A 1.

36 Aët. II 7, 1=DK28A 37.

37 Aët. II 11,4=DK28A 38.

38 Aët. II 13,8 = DK28A 39 .

39 Aët. II 26,2; II 28,5=DK28A 42.

40 DL IX 23=DK28A 1.

41 Strabo | 94= DK28A 44a. 
é da mesma natureza do cosmo, sendo composta de fogo e noite. Mas não é povoada por seres vivos. A vida aparece somente em um momento seguinte, como uma forma particular de existência da matéria, um produto novo no processo de evolução do mundo. Parmênides teve talvez a formidável intuição, que já fora de Anaximandro e será de Empédocles, da série de fases ou de graus do desenvolvimento da matéria, no qual vão sendo determinadas formas cada vez mais complexas de existência dotadas de qualidades novas. Eis o testemunho:

Empédocles... sustenta uma tese do gênero, isto é, que antes os membros singulares esparsamente vieram para o exterior da terra que estava como que grávida; depois se uniram e formaram a matéria do homem completo (solidi hominis materia), a qual é um misto de fogo e de água... Essa mesma opinião seguiu também Parmênides de Eléia que, excetuadas poucas coisas e de pouca importância, não discorda de Empédocles. $^{42}$

A linguagem poética que usaram Parmênides e particularmente Empédocles cobre de sombras efetivamente aquela que para nós hoje é uma certeza científica; os membros singulares que saem da terra, na imaginativa linguagem empedocliana, poderiam ser alusões a uma concepção que, no contínuo devir da matéria, vê uma série de tentativas através das quais são determinadas formas de organização cada vez mais complexas: a matéria orgânica, a substância viva e os seres animados. Com efeito, também os homens, como todos os seres vivos, são constituídos pelos mesmos elementos que compõem os fenômenos do cosmo. Parmênides diz "que os homens extraem a sua primeira origem da lama e que neles existem o calor e o frio dos quais tudo é composto". ${ }^{43}$

Até aqui vimos os testemunhos sobre Parmênides. Mas existem também todos os fragmentos autênticos do 9 em diante ${ }^{44}$ que nos falam sobre a importância que o Eleata atribuía à especulação científica. O fragmento 10 nos fala da natureza do éter e de todos os astros que estão no éter, da "obra destrutiva" do sol e do "vagar errante da lua do olho redondo"; 45 o fragmento 11 nos fala do nascimento da terra, do sol, da lua, da galáxia e de todos os astros; ${ }^{46}$ os fragmentos 14 e 15 nos dizem ainda sobre a lua e sobre o fato

42 Censor. de d. nat. 4,7.8 = DK28A 51.

43 DL IX 22 = DK28A 1.

44 Simplic. phys. 180, 8: "Tudo é igualmente cheio de luz e de noite escura que se equilibram ambos, já que toda coisa resulta do conjunto das duas".

45 Clem. Alex. Strom. V $138=$ DK 28B 10.

46 Simplic. de cael. 559,20 = DK28B 11. 
de que ela recebe sua luz do sol, ${ }^{47}$ o fragmento 13 nos fala de um Eros que "foi concebido primeiro entre todos os outros deuses". Quem concebe Eros é provavelmente a "deusa que tudo governa" à qual se faz referência no fragmento 12: devia certamente haver, mesmo se se perdeu para nós, uma verdadeira cosmogonia parmenídica propriamente dita, concebida sobre os traços da hesiódica, mas com aspectos originais. $\mathrm{Na}$ origem do pantheon parmenídico, antes de todos os deuses, a função central é desempenhada por uma divindade feminina, de cujo primeiro parto nasce precisamente Eros: o fato de ele ser o "primeiro entre todos os deuses" significa, muito provavelmente, que a essa figura divina Parmênides atribuía a tarefa de regular o nascimento dos seres particulares, como resultado da mistura dos dois princípios fundamentais. Se, por um lado, então, Parmênides se insere na linhagem de uma tradição de poesia e de reflexão sobre Amor como princípio cósmico e cosmogônico, que tem a função de "unir", "formar" e "levar ao nascimento", por outro lado, ele leva a cabo o processo de universalização que nasceu precisamente da crítica racionalista ao princípio da teogonia tradicional. O Eros de Parmênides simboliza, precisamente, aquela força imanente ao mundo dos fenômenos, que torna possível a conjunção dos opostos e, em definitivo, o aparecer no cosmo de cada um dos seus aspectos particulares, na sua determinação e especificidade. $\mathrm{O}$ mesmo pode ser dito dos homens.

No centro do universo há, portanto, a deusa que tudo governa: ela é "causa da geração de todas as coisas" ${ }^{48}$ dos deuses, das coisas e dos homens, através da força divina de Eros, força vital que se expande pelo universo, que regula e determina a união dos elementos contrários do fogo e da noite, assim como da fêmea e do macho. A união sexual é vista, com efeito, por Parmênides como um caso particular da lei geral que vê os opostos se procurarem e se unirem. Da antropologia parmenídica sobraram somente alguns traços de uma doutrina embriológica ou embriogenética, que se refere ao problema, muito discutido na Antigüidade, da diferenciação dos sexos. O fragmento 18 nos diz que a formação regular dos corpos no útero materno e a determinação do sexo do nascituro dependem do equilíbrio que se instaura na mistura das sementes geradoras paternas e maternas. Para a concepção, então, concorrem as forças (virtutes=dynameis) seja do homem seja da mulher: se elas se harmonizam, nascerão homens e mulheres bem formados; homens se a concepção ocorre na parte direita do útero, mulheres se ocorre na esquerda $;^{49}$ se não se harmonizam, 
o sexo do nascituro será atormentado, isto é, existirão homens efeminados ou mulheres masculinas. ${ }^{50}$ A propósito da geração dos filhos, pode-se falar com certeza de duas escolas de pensamento na Antigüidade: por um lado, sustentava-se que o elemento feminino não servia para a geração, sendo a mulher simplesmente um receptáculo da força geradora masculina; eram dessa opinião Hipon, Diógenes de Apolônia, Demócrito, Aristóteles e os Estóicos; por outro lado, sustentava-se que na concepção dos filhos contribuíam seja as forças do homem, seja aquelas da mulher; eram dessa opinião Alcméon, Empédocles, Anaxágoras, Epicuro e o próprio Parmênides.

3. Remeter Parmênides ao seu tempo, portanto, não significa diminuir sua importância, mas, ao contrário, buscar a explicação do seu livro não só nos livros dos outros filósofos, como também no ambiente físico, político e cultural que o circunda, enriquecendo-o, definitivamente, com uma espessura ou uma concretude que o retiram da abstração do pensamento puramente "filosofante". Essa operação, que também do ponto de vista político pode levar a resultados interessantes, foi tentada por Antonio Capizzi, em muitos ensaios e especialmente em um livro de trinta anos atrás. ${ }^{51}$ A proposta de Capizzi consistia fundamentalmente em apontar no poema, ao lado dos planos lingüístico e ontológico, também um plano político de significados do pensamento parmenídico. Proposta certamente importante e digna de ser desenvolvida, porque sabemos que Parmênides não foi somente filósofo, mas um homem bastante inserido nos acontecimentos históricos da sua cidade. $\mathrm{O}$ limite da sua proposta consistia, porém, e talvez precisamente pelo entusiasmo com o qual Capizzi defendia as sua teses, em acabar por sobrepor o plano político ao lingüístico e ao filosófico, mais do que completar estes últimos com o primeiro. Discutimos sobre isso, Capizzi e eu, longamente, durante anos, em seminários, congressos, artigos, ensaios e conversas privadas, sempre com o respeito e a estima que nutríamos um pelo outro e com o comum amor pela verdade, que é o único pressuposto que torna profícuas as discussões e o próprio dialogar. Depois de tantos anos, embora permanecendo ainda convicto com relação às minhas teses, quero, porém, aqui prestar homenagem ao amigo desaparecido reapresentando a sua proposta, e esperando que ela possa encontrar ainda outras ocasiões para discussão. ${ }^{52}$

50 Cael. Aurel. morb.chron. IV 9 = DK28B 18.

51 Capizzi, A. La porta di Parmenide. Roma: 1975.

52 Tudo aquilo que diremos se baseará no volume citado na nota precedente, ao qual remeto também para todas as citações dos passos, dos testemunhos, das referências aos autores e às evidências arqueológicas e históricas. 
O que sabemos, de concreto, de Parmênides na sua cidade? Que Eléia foi fundada pelos fócios e que foi bem governada por Parmênides e por Zenão; que Parmênides ditou novas leis para a sua cidade; que suas leis foram tão boas que os cidadãos de Eléia todos os anos juravam permanecer fiéis a elas. Sabemos pouco, pois, se olharmos apenas para as alusões dos filósofos e doxógrafos; muito mais, entretanto, se olharmos para a história das cidades do Mediterrâneo daqueles tempos. É um fato que uma figura central no poema parmenídico é Dike, a justiça: ora, se desde a Antigüidade o prólogo do poema foi lido em termos que destacam sua capacidade de alusão, as referências alusivas deviam servir para fazer com que seus concidadãos identificassem objetos precisos e para localizar o itinerário da viagem que Parmênides realiza até a presença da deusa. Quanto a isso podem nos ajudar os testemunhos arqueológicos: Parmênides, com efeito, no seu prólogo faz referência a localidades existentes em Eléia e não a regiões metafísicas ou astronômicas. A "via do Nume" que é citada no fragmento 1, que conduz através de todos os bairros, é efetivamente a Via Rosa, descoberta pelos arqueólogos, que unia o porto fluvial norte da cidade à colina, e, em seguida, ao outro porto de Eléia. A via era ladeada por fileiras de choupos (as filhas do Sol do verso 9) e quando diz que elas, nos versos 9-10, são representadas no ato de erguer as mãos para o alto e livrar as cabeças dos véus, ele quer representar o fato de que os choupos, à medida que a estrada deixa o vilarejo na sombra, rumo à colina que fica em plena luz, passam a ter os seus topos iluminados, e quase parece que seus ramos são estendidos, arrancando da cabeça os véus de sombra que a Noite, senhora da vertente setentrional, tinha colocado. A porta da qual fala Parmênides é a Porta Arcaica, descoberta pelos arqueólogos, que separava e unia os dois portos ao norte e ao sul da cidade; o fato de que seja Dike quem possui as chaves que abrem ou fecham aquela porta significa que o fato de estar aquela porta aberta ou fechada é exatamente um fato político, de justiça. Em certa fase da vida da cidade, alguém tinha decidido em favor da separação entre os dois portos, barrando a porta que fechava o desfiladeiro. Parmênides convence precisamente os seus concidadãos que era justo reabrir a porta e a artéria, restabelecendo as relações normais entre as partes da cidade e fazendo dos muitos aste, vilarejos, uma única polis, uma só cidade.

Em certo momento da sua história, houve uma secessão em Eléia: fato freqüente nas cidades da Magna Grécia. Ora, uma secessão de uma parte da cidade pode ocorrer por vários motivos; pode-se verificar um contraste entre dois ou mais grupos étnicos que contribuíram para fundar a cidade, por exemplo, como no caso exato das "colônias mistas" de Turi ou de Gela. Mas Heródoto diz que Eléia foi fundada somente pelos fócios que, fugidos da pátria para não 
cair sob o domínio dos persas, depois de uma parada de cinco anos em Alália, fugiram também dali depois de uma batalha desastrosa no mar da Sardenha contra etruscos e fenícios. Em Eléia poderiam, então, ter existido dois grupos pelo menos, os fócios de Alália e metecos aqueus, mas também sibaritas; depois de 510, com efeito, exilados sibaritas se refugiaram nas costas tirrênicas. Mais provável é que tenha ocorrido uma secessão da plebe após um conflito social, fato freqüentíssimo na história das cidades gregas, ${ }^{53}$ entre os séculos VI e V, como sabemos que efetivamente aconteceu em Gela, em Siracusa e nas cidades pitagóricas do Jônico. Conflito étnico ou social, as situações de Eléia e de Parmênides se ligam muito bem com dois elementos constantes que aparecem na história nesses casos: por um lado, a figura do "embaixador" que "persuade' os expatriados a retornarem, ou os que ficaram a abrirem as portas, figura que, freqüentemente, torna-se o chefe político da comunidade reconstituída e, por outro lado, a nova constituição que nasce da reconciliação dos dois grupos. Ambos os elementos adaptam-se perfeitamente a Parmênides, embaixador, chefe político e legislador das novas leis; não faltam, no prólogo, as referências ao tríplice papel de Parmênides: ele foi guiado por direito e justiça, está à altura das aurigas imortais, sendo que auriga era uma denominação comum dos chefes políticos. Há ainda as referências filosóficas do fragmento 8 à homogeneidade, à compacidade "daquilo que é", que aludem a uma dimensão da atividade política: dar compacidade política e uniformidade de costumes à cidade em perigo.

A polêmica forte do fragmento 6, no qual se fala das famosas três vias, adquire nova luz. Da primeira se diz "que é", que efetivamente existe; das outras duas se diz que é necessário manter-se distante: delas, uma não existe absolutamente, a outra é aquela na qual vão errando os "homens com duas cabeças". "Vão errando" no texto é plattontai, que vem de platto, ou plasso, que significa plasmar, modelar, mas também exprimir com gestos e, então, inventar, fabricar falsamente, excogitar mentindo. ${ }^{54}$ No mais, a antítese entre a primeira e as outras duas vias é caracterizada, no texto, pelos termos "segurança", para a primeira, e "insegurança" e "intransitável", para as outras. Ora, a incapacidade dos homens com duas cabeças de entender e de se fazerem entender como se fossem "cegos e surdos", ou mesmo mudos, e o fato de que usam uma "língua retumbante", isto é, um retumbar de sons mais do que uma linguagem, nos levam claramente a entender que estes homens falam uma

53 Mas não somente: que se pense também em Roma e na secessão do monte Aventino, sobre a qual fala Menenio Agrippa no seu famoso apólogo.

540 verbo é próximo de plazo, que significa desviar, conduzir para fora do reto curso, desencaminhar. Capizzi traduz, de fato, por "simulam". 
língua estrangeira. Nos remetem, pois, a uma temática comum aos gregos, aquela da heteroglossia; era concepção bastante comum entre os gregos considerar um balbucio incompreensível toda língua não grega. Os "mortais ignorantes", então, que não sabem falar nem entender o logos, o discurso em grego, são, então, estrangeiros.

Mas quem são esses estrangeiros que simulam com ambigüidade de intenção? Se pensarmos que Parmênides não nos é descrito como um grande viajante, o círculo se restringe às línguas não gregas faladas na Itália e nas ilhas do Tirreno, e, pois, às etnias itálicas, fenícias ou etruscas. Se pensarmos no tom de desprezo que Parmênides usa com relação a elas, na sua ignorância e incapacidade, devemos pensar nas derrotas destes estrangeiros levada a cabo pelos gregos. Isso imediatamente nos faz excluir as etnias itálicas, e, em particular, os Lucanos, que, no final do século VI e no início do V, mantinham boas relações com os gregos das costas; tanto é verdade que assimilaram deles muitos elementos, dentre os quais o alfabeto, e só mais tarde iniciaram as suas incursões na Campânia. Então, permanecem os fenícios ou os etruscos: no tempo de Parmênides (nascido no fim do séc. VI), com efeito, os fenícios tinham sofrido uma grave derrota em Hímera (em 480) e os etruscos em Cuma (em 474), por obra dos Gregos de Siracusa. Mas se pensarmos nos termos marítimos do fragmento 6 (o ser arrastado, o "arremessar", o caráter ensurdecedor e retumbante das palavras desses homens com duas cabeças, são termos que, em geral, os escritores gregos mais antigos aplicam às ondas do mar ou aos ventos), podemos verossimilmente pensar nos fenícios. Naqueles fenícios "falsos" que já apareciam na Odisséia e que Parmênides chama de "simuladores". Em grego, existia realmente um termo, phoinikeliktes (literalmente: semelhante aos fenícios), que significava enganador: tratava-se, então, de um cliché grego, transmitido depois à cultura romana. Simuladores e "duplos", fazendo referência à duplicidade cartaginesa da qual falará ainda Virgilio na Eneida.

Se relacionarmos todos esses fatores, ao lado da filosofia e da investigação naturalista, é possível, ainda, entrever um terceiro nível de leitura do poema parmenídico. Por volta de 480-470, data provável de composição do poema, aconteceu outro fato importante: a emergência da potência de Pitecusa, conquistada precisamente por Híeron de Siracusa em $474 .{ }^{55}$ Eléia, como outras

55 Sabemos que o domínio não foi longo: depois de uma terrível erupção do Epomeu, que obrigou os Siracusanos a deixá-la, a ilha foi conquistada pelos napolitanos, na segunda metade do séc. V, que a mantiveram em sua posse até o ano de 82, quando passou aos Romanos; mas Augusto, em 29 a.C., a restituiu aos Napolitanos em troca de Capri. 
cidades da costa da Campânia, via assim ameaçada sua própria independência pela talassocracia siracusana que a pressionava ao sul e ao norte. A posição política de Parmênides emerge, então, em primeiro lugar, como um convite aos Eleatas a não tentarem se defender dos Siracusanos, recorrendo à ajuda dos seus inimigos derrotados, os Fenícios de Cartagena. Com efeito, a batalha de Hímera, que teve lugar dez anos antes, e que terminou com a derrota de Amílcar, por obra de uma coalizão entre Siracusanos e Agrigentinos, tinha entrado desde então no imaginário grego como um fato simbólico, tanto é verdade que Píndaro tinha exaltado aquela vitória siracusana, comparando-a às duas grandes vitórias obtidas no mesmo ano de 480 pelos gregos continentais sobre os persas, a vitória ateniense de Salamina e a vitória espartana de Platéia.

Mas, se a talassocracia siracusana atravessava, por volta de 470, o seu momento mágico, estendendo-se do Etna ao Epomeu, também a talassocracia púnica, não obstante a derrota de Hímera, gozava de boa saúde; assim, se podia dizer que o cerco fenício, por sua vez, circundava o cerco siracusano: estabelecidos na Sicília e na Sardenha, comercialmente presentes em todo o Tirreno, até Marselha, e até mesmo no Lácio, se pode dizer que os fenícios sitiavam os siracusanos sitiantes de Eléia.

Donde as sugestões políticas de Parmênides aos eleatas, que estavam no centro dessas coalizões e dessas contraposições. As três "vias" do fragmento 6 se delineiam assim como:

1. a "via que é", que se realiza somente na compacidade, de onde a necessidade de uma cidade única, fortemente coesa, com leis imutáveis;

2. a "via que não é", que é aquela da continuação da secessão, instaurando assim uma situação de debilidade muito arriscada naquele momento histórico;

3. a terceira via, da qual é necessário que mesmo os eleatas se mantenham distantes, e que é aquela de deixar-se enganar pela astúcia dos fenícios e cair, assim, na mesma armadilha reservada aos seus outros aliados gregos, como, por exemplo, os selinuntinos, aliados dos fenícios, que, exatamente por obra desses, viram ser destruída sua cidade.

Por esse ponto de vista, o poema de Parmênides seria também um "manifesto" político dirigido às três principais coalizões que devem ter se formado em Eléia, depois da fundação da colônia siracusana de Ísquia: os intransigentes partidários da secessão sem limite; os filofenícios que se iludiam de encontrar, naqueles bárbaros, aliados seguros para se oporem aos siracusanos, e os pan-helênicos, convictos de que de modo algum se deveria 
infringir aquela aliança grega que, dez anos antes, havia arruinado os bárbaros. É lícito supor que Parmênides foi o arauto dessa terceira facção, e que essa foi a facção que prevaleceu, uma vez que ele se tornou legislador e chefe político de sua cidade. Para concluir com Capizzi: “o poema parmenídico pertence, pois, à história da política mediterrânea dos gregos, pelo menos da mesma forma que pertence à história da sua cultura e de seu pensamento especulativo". 